\title{
ORBIS (Open Research Biopharmaceutical Internships Support) - building bridges between academia and pharmaceutical industry to improve drug development
}

\section{Emilia Jakubowska}

Chair and Department of Pharmaceutical Technology, Faculty of Pharmacy, Poznan University of Medical Sciences, Poznan

(iD) https://orcid.org/0000-0002-7492-9045

\section{Sharon Davin}

Applied Process Consulting Ltd., Dublin, Ireland

(iD) https://orcid.org/0000-0003-0578-8741

\section{Aleksandra Dumicic Dumicic}

Zentiva k.s., Prague, Czech Republic

(iD) https://orcid.org/0000-0002-2347-1409

\section{Grzegorz Garbacz}

Physiolution $\mathrm{GmbH}$, Greifswald, Germany

(iD) https://orcid.org/0000-0003-4511-0329

\section{Anne Juppo}

University of Helsinki, Division of Pharmaceutical Chemistry and Technology, Formulation and Industrial Pharmacy Unit, Helsinki, Finland

(iD) https://orcid.org/0000-0003-1805-8991

\section{Bożena Michniak-Kohn}

Center for Dermal Research and Ernest Mario School of Pharmacy, Rutgers, The State University of New Jersey, Piscataway, New Jersey, USA

(iD) https://orcid.org/0000-0002-3858-158X

\section{Piotr J. Rudzki}

Łukasiewicz Research Network - Pharmaceutical Research Institute, Warsaw, Poland

(iD) https://orcid.org/0000-0002-4622-4849

\section{Wojciech Smułek}

Institute of Technology and Chemical Engineering Poznan University of Technology, Poznan, Poland (iD) https://orcid.org/0000-0001-5377-9933

\section{Clare Strachan}

University of Helsinki, Division of Pharmaceutical Chemistry and Technology, Formulation and Industrial Pharmacy Unit, Helsinki, Finland

(iD) https://orcid.org/0000-0001-9180-5856

\section{Oleg Syarkevych}

JSC Farmak, Kyiv, Ukraine

(iD) https://orcid.org/0000-0002-4236-5927

\section{Lidia Tajber}

School of Pharmacy and Pharmaceutical Sciences, Trinity College Dublin, College Green, Dublin 2

(D) http://orcid.org/0000-0003-1544-6796

\author{
Janina Lulek \\ Chair and Department of Pharmaceutical \\ Technology, Faculty of Pharmacy, Poznan University \\ of Medical Sciences, Poznan, Poland \\ (iD) https://orcid.org/0000-0002-5567-9909 \\ Corresponding author: jlulek@ump.edu.pl
}

DOI: https://doi.org/10.20883/medical.419

Keywords: drug discovery and design, pharmaceutical formulation, research and development, solid state materials, pharmaceutical technology, biomedical analysis

Published: 2020-01-31

How to Cite: Jakubowska E, Davin S, Dumicic AD, Garbacz G, Juppo A, Michniak-Kohn B, Rudzki PJ, Smułek W, Strachan C. Syarkevych O, Tajber L, Lulek J. ORBIS (Open Research Biopharmaceutical Internships Support) - building bridges between academia and pharmaceutical industry to improve drug development. JMS [Internet]. 2020 Mar 31;89(1):e419. doi:10.20883/medical.419

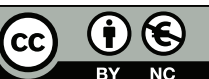

(C) 2020 by the author(s). This is an open access article distributed under the terms and conditions of the Creative Commons Attribution (CC BY-NC) licencse. Published by Poznan University of Medical Sciences 
aim to improve the preclinical pathway of medicine development through increased Research and Development (R\&D) productivity, especially focusing on processes and technologies which address the challenge of poor drug bioavailability. The RISE scheme supports secondments, meaning that early stage and experienced researchers are sent to consortium partner institutions to advance studies on pharmaceutical preformulation, dosage forms and drug delivery systems and methods of biopharmaceutical evaluation. The ORBIS project enables secondees to gain news skills and develop their competences in an international and intersectoral environment, strengthening the human capital and knowledge synergy in the European pharmaceutical R\&D sector.

\section{Introduction}

ORBIS (Open Research Biopharmaceutical Internships Support, grant agreement no. 778051) is an international and intersectoral project awarded $€ 2,268,000$ by the European Commission under the Research and Innovation Staff Exchange (RISE) call of Marie Skłodowska-Curie Actions (MSCA), Horizon 2020 programme (H2020MSCA-RISE-2017). This four-year project was launched on $1^{\text {st }}$ March 2018.

ORBIS (Figure 1) is one of the largest projects and consortia of the RISE programme, comprising 10 beneficiaries and partners; these include six academic institutions and four pharmaceutical companies located in seven countries (Figure 2). This project will enable over 200 researchers to advance their research and other skills through secondment placements. Poznan University of Medical Sciences (PUMS, Poland) is the project coordinator and the grant is managed by the project chair, Professor Janina Lulek, Head of the Chair and Department of Pharmaceutical Technology at PUMS.

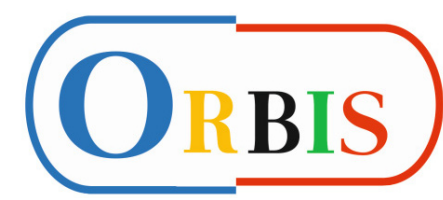

Figure 1. ORBIS official logo

\section{Research Project Objectives}

The current process of drug development is lengthy and inefficient. When developing a new chemical entity only one out of approximately 10,000 molecules enters the market as a drug. The situation is no better for generic or value- added medicinal products, where the active pharmaceutical ingredient (API) is already wellknown: commencing from the first laboratory trials, it takes a minimum of four years of intensive activities for the simplest generic drug product to reach the market. The societal demand for more effective medicines has created a challenge of supply within the pharmaceutical industry. To address this gap, ORBIS proposes that the time for the medicinal product to reach the patients might be reduced by improving early stage $R \& D$ productivity. The overarching objective of ORBIS is to form an international and intersectoral academic and industrial network to address this challenge (Table 1). This consortium was built on pre-existing collaboration that has expanded into the current ORBIS group (Figure 2). The project aims to improve the preclinical pathway of medicine development, concentrating on processes and technologies to address poor drug bioavailability.

The close research cooperation between the project partners, as well as knowledge synergy and transfer between the academic and industrial sectors, has created a stimulating environment for employees and PhD students to advance their individual career and transferrable skills during research visits (ORBIS secondments) and those interactions are the core enablers of the consortium objectives (Table 2).

\section{Research Plan and Basic Concept}

The core and vehicle for accomplishing the ORBIS project objectives are secondments, i.e. 1to 12-month long research and training visits of early stage and experienced researchers at partner institutions. PhD students and employees from the European universities can travel abroad 
Table 1. Institutions participating in ORBIS project

\begin{tabular}{|c|c|c|}
\hline $\begin{array}{l}\text { Institution name } \\
\text { and acronym }\end{array}$ & Location & Project role/ short description \\
\hline $\begin{array}{l}\text { Poznan University } \\
\text { of Medical } \\
\text { Sciences (PUMS) }\end{array}$ & Poznan, Poland & $\begin{array}{l}\text { Project beneficiary and coordinator. Apart from the project management and } \\
\text { organization, several departments of Faculty of Pharmacy are engaged in sending and } \\
\text { hosting secondees. PUMS expertise includes: pharmaceutical preformulation, drug } \\
\text { design and delivery, physical chemistry, pharmaceutical and biopharmaceutical } \\
\text { analysis, pharmacokinetics. }\end{array}$ \\
\hline APC Ltd. (APC) & Dublin, Ireland & $\begin{array}{l}\text { Project beneficiary. APC specializes in integrating innovative process performance } \\
\text { across a medicine's life cycle, from early Phase development to manufacturing support. } \\
\text { APC's research platforms and associated information deliverables help the global bio/ } \\
\text { pharma sector accelerate the development and launch of their medicines. }\end{array}$ \\
\hline JSC Farmak (FMK) & Kyiv, Ukraine & $\begin{array}{l}\text { Project beneficiary. FMK is the leading Ukrainian developer of generic and innovative } \\
\text { dosage forms. Small, pilot and large-scale manufacturing facilities. }\end{array}$ \\
\hline $\begin{array}{l}\text { Łukasiewicz } \\
\text { Research Network } \\
\text { - Pharmaceutical } \\
\text { Research Institute } \\
\text { (PRI) }\end{array}$ & Warsaw, Poland & $\begin{array}{l}\text { Project beneficiary. PRI develops API manufacturing technologies, translating academic } \\
\text { research into practical solutions for industry. Expertise covers laboratory scale } \\
\text { synthesis and scale-up, development of formulations, analytics and pharmacokinetic } \\
\text { studies. API manufacturing facilities. }\end{array}$ \\
\hline $\begin{array}{l}\text { Physiolution GmbH } \\
\text { (PHY) }\end{array}$ & $\begin{array}{l}\text { Greifswald, } \\
\text { Germany }\end{array}$ & $\begin{array}{l}\text { Project beneficiary. PHY develops biorelevant test methods for assessing in vitro } \\
\text { biopharmaceutical properties of the drug substances and drug products. }\end{array}$ \\
\hline $\begin{array}{l}\text { Poznan University } \\
\text { of Technology } \\
\text { (PUT) }\end{array}$ & Poznan, Poland & $\begin{array}{l}\text { Project beneficiary. Researchers of the Institute of Chemical Technology and } \\
\text { Engineering, Faculty of Chemical Technology, provide knowledge in areas of inorganic } \\
\text { and organic chemical technology, chemical engineering, polymer technology, chemical } \\
\text { analysis and biotechnology. }\end{array}$ \\
\hline $\begin{array}{l}\text { University of } \\
\text { Helsinki (UH) }\end{array}$ & Helsinki, Finland & $\begin{array}{l}\text { Project beneficiary. The Formulation and Industrial Pharmacy unit of the Division of } \\
\text { Pharmaceutical Chemistry and Technology focuses on the translation of a drug } \\
\text { molecule into a medicine. Expertise is offered in novel spectroscopic techniques and } \\
\text { manufacturing technologies of oral solid dosage forms. }\end{array}$ \\
\hline $\begin{array}{l}\text { Trinity College } \\
\text { Dublin (TCD) }\end{array}$ & Dublin, Ireland & $\begin{array}{l}\text { Project beneficiary. Trinity Pharmacy \& Pharmacology is joint } 45 \text { in the world by subject } \\
\text { (Pharmacy and Pharmacology) and the School of Pharmacy and Pharmaceutical } \\
\text { Sciences is the leading Pharmacy educator in Ireland. The expertise includes } \\
\text { pharmaceutical preformulation, engineering of solid-state materials and advanced oral } \\
\text { and pulmonary formulations. }\end{array}$ \\
\hline Zentiva (ZNT) & $\begin{array}{l}\text { Prague, Czech } \\
\text { Republic }\end{array}$ & $\begin{array}{l}\text { Project beneficiary. ZNT is an international pharmaceutical company that develops, } \\
\text { manufactures and distributes generic and value-added medicinal drug products for oral } \\
\text { and parenteral drug delivery. }\end{array}$ \\
\hline $\begin{array}{l}\text { Rutgers, the State } \\
\text { University of New } \\
\text { Jersey (RUTG) }\end{array}$ & New Jersey, USA & $\begin{array}{l}\text { Project partner. RUTG is a member of the "Big } 10 \text { " top universities in the U.S. with } \\
70,000 \text { undergraduates \& graduates \&over } \$ 750.8 \text { million in research monies. The } \\
\text { School of Pharmacy is in the top ten pharmacy schools in the US. Center for Dermal } \\
\text { Research founded in } 2011 \text { is the only academic Center in NJ dedicated to } \\
\text { pharmaceutical skin research. }\end{array}$ \\
\hline
\end{tabular}

to pharmaceutical companies and Rutgers University, while staff from the industrial members visit foreign academic partners, meaning that all secondments must be international and mostly intersectoral.

ORBIS activities are organized in 7 Work Packages (WP), each addressing a specific project objective to streamline the scientific progress, knowledge transfer or dissemination.

The aim of WP1: Drug substances and pharmaceutical preformulation is to translate the discovery synthesis of a drug substance (API) into technology development and investigate the solid-state physicochemical characteristics of APIs. The overarching goal is to improve unfavourable biopharmaceutical characteristics of APIs, i.e. poor solubility and/or dissolution. To accelerate small molecule process design, several technological platforms are explored to deliver an improved product better suited for further formulation development. Research employs advanced analytical equipment to investigate the intrinsic, solid state and derived properties of the APIs and their forms.

The purpose of WP2: Dosage forms and drug delivery systems is to design, develop and test new drug carriers and dosage forms for oral and topical delivery of drugs. Examples of oral formulations are novel liposomes, polymeric nanoand microparticles, minitablets, self-microemul- 


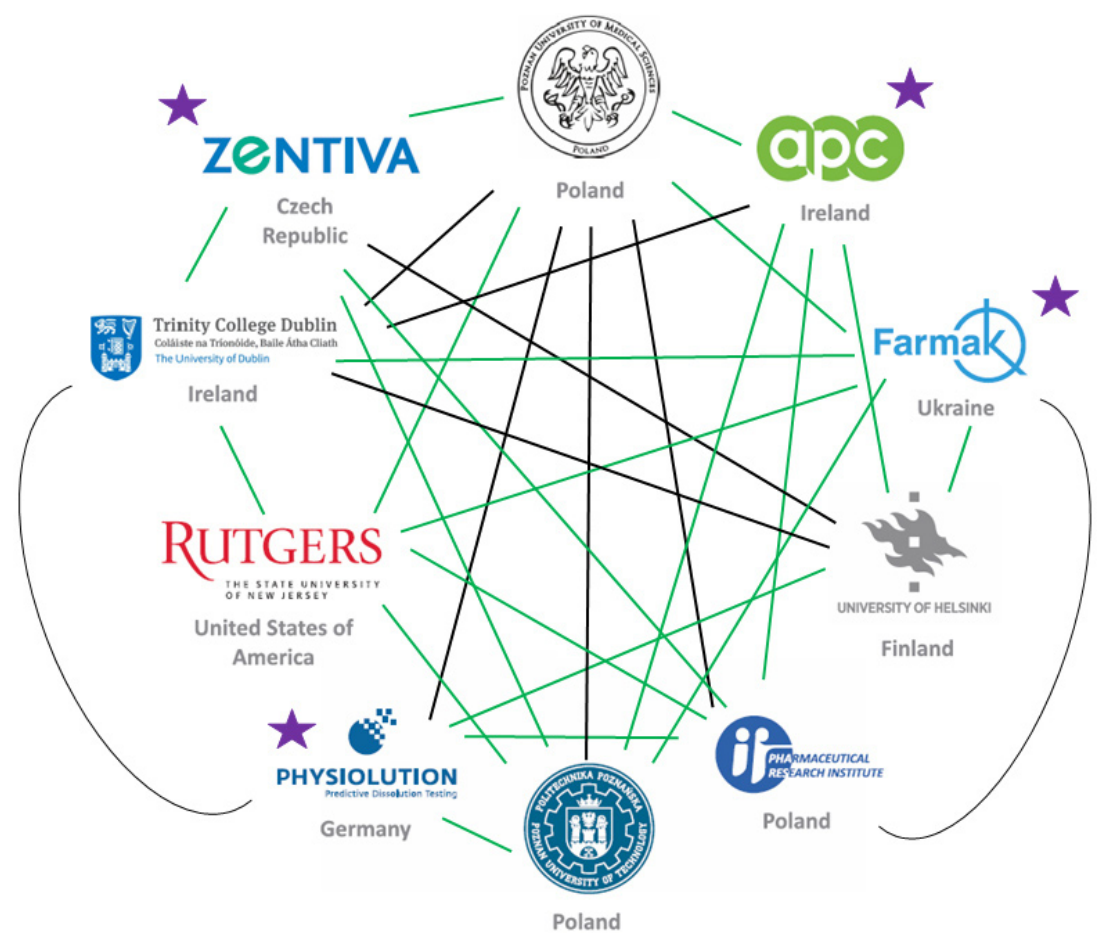

Figure 2. ORBIS network. Pre-ORBIS collaboration (black lines) and new ORBIS collaboration (green lines). Industry partners are marked with a star

Table 2. ORBIS project objectives

\begin{tabular}{|c|c|}
\hline $\begin{array}{l}\text { To improve the process development of drug substances by innovating } \\
\text { synthesis and evaluation of active materials and their physical forms. }\end{array}$ & $\begin{array}{l}\text { To enable hands-on and relevant industrial training of } \\
\text { early stage researchers including a range of "soft skills". }\end{array}$ \\
\hline $\begin{array}{l}\text { To advance pharmaceutical preformulation studies by developing new } \\
\text { industry-relevant methods of evaluation of drug substances physical } \\
\text { forms in the biopharmaceutical context. }\end{array}$ & $\begin{array}{l}\text { To foster "communal" academia-industry open } \\
\text { collaboration. }\end{array}$ \\
\hline $\begin{array}{l}\text { To formulate advanced drug delivery systems and optimize } \\
\text { manufacturing of oral dosage forms. }\end{array}$ & \multirow{3}{*}{$\begin{array}{l}\text { To support industry-academia research leading to joint } \\
\text { publications, presentations and enabling staff transfer } \\
\text { between these two sectors. }\end{array}$} \\
\hline $\begin{array}{l}\text { To better understand drug transport across the skin and develop topical } \\
\text { and transdermal delivery systems. }\end{array}$ & \\
\hline $\begin{array}{l}\text { To innovate the biopharmaceutical evaluation of dosage forms and drug } \\
\text { delivery systems by improving the testing approaches and methods of } \\
\text { bioanalysis. }\end{array}$ & \\
\hline
\end{tabular}

Table 3. Overview of ORBIS summer schools and workshops

\begin{tabular}{|c|c|c|}
\hline Event name & Organizing institutions & Place and date \\
\hline $\begin{array}{l}1^{\text {st }} \text { School on pharmaceutical preformulation testing } \\
\text { of APIs and dosage forms. }\end{array}$ & TCD \& APC & \multirow{2}{*}{ Dublin, 12-14 ${ }^{\text {th }}$ June 2019} \\
\hline $\begin{array}{l}\text { Open Workshop on process development of drug } \\
\text { substances. }\end{array}$ & FMK & \\
\hline $\begin{array}{l}2^{\text {nd }} \text { ORBIS Summer School on Oral Dosage Forms: } \\
\text { Fundamentals, Challenges and Future Opportunities }\end{array}$ & UH \& ZNT & \multirow{2}{*}{$\begin{array}{l}\text { Helsinki, } 18-20^{\text {th }} \\
\text { September } 2019\end{array}$} \\
\hline $\begin{array}{l}\text { ORBIS Workshop on Dosage Forms and Drug } \\
\text { Delivery Systems. }\end{array}$ & UH & \\
\hline $\begin{array}{l}3^{\text {rd }} \text { School on topical and transdermal drug delivery } \\
\text { systems. }\end{array}$ & PUMS \& RUTG & $\begin{array}{l}\text { Poznan, } 29^{\text {th }} \text { September } \\
-1^{\text {st }} \text { October } 2020\end{array}$ \\
\hline $\begin{array}{l}4^{\text {th }} \text { School on biopharmaceutical evaluation } \\
\text { of dosage forms and drug delivery. }\end{array}$ & ZNT \& PRI & \multirow{2}{*}{ Prague, September 2021} \\
\hline $\begin{array}{l}\text { Open Workshop on biopharmaceutical evaluation } \\
\text { of dosage forms and drug delivery systems. }\end{array}$ & PHY & \\
\hline
\end{tabular}


sifying systems or mesoporous materials, while topical pharmaceutical dosage forms include liquid (ionic liquids, microemulsions), semi-solid (hydrogels, organogels, creams) and adhesive (patches). This work package employs a variety of advanced methods to analyse the developed formulations, including novel imaging and structure analysis techniques and in vitro skin permeation tests.

WP3: Biopharmaceutical evaluation of dosage forms and drug delivery systems focuses on the development of biorelevant methods for in vitro dissolution and release testing, simulating conditions that act on dosage forms during their gastro-intestinal passage. An additional aim is to advance bioanalytical methods, including biological sample preparation techniques, reducing HPLC analysis time and assessing validation parameters according to the European Medicines Agency guidelines [1].

In addition to the scientific WPs, ORBIS is supported by four other WPs. WP4: Training especially concerns early stage researchers. Secondments are an opportunity to become familiar with new research topics and intersectoral environments, learn new methodologies and techniques as well as develop transferrable scientific and "soft" skills, further increasing employability of the young researchers. WP5: Management deals with the strategic management and organization of this large consortium, while WP6: Communication and dissemination increases the project impact, visibility and dissemination of results. WP7: Ethics monitors the handling of ethical issues related to the project and it is supported by the Honorary Ethical Advisory Board, an independent body of external experts.

\section{Research Methodology}

Methods include API synthesis, preformulation studies, manufacturing, analytics (including bioanalytics), continuous processing, quality by design and new testing methodology design. Also, a blend of experimental and computational techniques is used to accomplish the research goals. Experts in the various research areas from the consortium are involved in the design of the methods and approaches, amalgamating the expertise in the multidisciplinary, international and intersectoral consortium. The partners are integrating their common research protocols and filling gaps in individual infrastructures.

\section{Measurable effects and expected results}

Several deliverables and milestones are aligned with the objectives of the ORBIS project. The WP1 team will demonstrate a continuous operation of synthesis/crystallisation processes for APIs relevant to ORBIS and develop a strategy to improve the solubility/permeability of BCS class II and IV APIs. A public report on perspectives of API manufacturing and advances in preformulation studies will be jointly prepared.

The WP2 milestones comprise the demonstration of oral formulation advancements accomplished as a part of ORBIS (e.g. minitablets, novel drug carriers) and improvements in formulation of transdermal dosage forms. A WP2 deliverable will be a public report on new insights into oral dosage forms and delivery systems as well as novel approaches in topical and transdermal drug delivery.

The main impact of WP3 will be the successful evaluation of bioanalytical methods for selected APIs. The WP3 team will prepare a report on pharmacokinetics driven development of dosage form specifications and estimation of pharmacokinetics based on in vitro data.

To date, after 24 months of project activity, 221 months of secondments have been completed and have started to deliver tangible research outputs, such as new research collaborations and publications [2-6].

Apart from the scientific deliverables and milestones, the progress of the ORBIS project is measured by completing activities related to training, management and dissemination. Four summer schools and workshops for ORBIS participants are the outcomes of WP4 (Table 3). These events involve lectures delivered by worldclass researchers, hands-on workshops and demonstrations of relevant techniques, as well as are an opportunity to showcase the organizing partners' capabilities and the results of secondments. The summer schools and workshops are also excellent networking events for strengthening the relationships and formulating new ideas 
for cooperation between the ORBIS partners and reaching beyond the timeframe of this project.

To date, the project has also successfully achieved its managerial deliverables - including two out of the three major consortium meetings (kick-off, mid-term and planned final conference) and one out of the two progress reports. Project activities and outputs can be followed on the ORBIS website and social media channels established as dissemination deliverables [7].

A goal of ORBIS is to have 504 months of secondments achieved by February 2022. This will lead to over two hundred researchers from European academia and pharmaceutical companies gaining new skills and experience in an international and interprofessional environment. A key impact of the ORBIS project will be increased competence and employability of researchers in the European pharmaceutical sector. Through new personal ties, academic and industrial institutions will form close cooperation and partnerships beyond the scope and duration of ORBIS. The project will enhance the transfer of knowledge in the pharmaceutical sector, ultimately strengthening human capital in research and innovation under the MSCA-RISE action.

\section{Acknowledgements}

\section{Conflict of interest statement}

The authors declare no conflict of interest.

\section{Funding sources}

This project has received funding from the European Union's Horizon 2020 Research and Innovation Programme under the Marie Skłodowska-Curie grant agreement No. 778051 and the Ministry of Science and Higher Education of Poland fund for supporting internationally co-financed projects in 2018-
2022 (agreements No 3898/H2020/2018/2 and 3899/ $\mathrm{H} 2020 / 2018 / 2$ ). This article reflects the authors' view only. Neither the Research Executive Agency nor the Polish Ministry of Science and Higher Education may be held responsible for any use of the information contained therein.

The authors gratefully acknowledge Prof. Andrzej Kutner, Dr. Bartłomiej Milanowski and Bożena Raducha for their contribution to grant proposal preparation and project launching. The ORBIS project team, including researchers and administrative staff, is acknowledged for excellent cooperation and commitment.

\section{References}

1. Guideline on bioanalytical method validation. https:// www.ema.europa.eu/en/bioanalytical-method-validation. Accessed 2020 March 11.

2. Kaza M, Karaźniewicz-Łada M, Kosicka K, Siemiątkowska A, Rudzki PJ. Bioanalytical method validation: new FDA guidance vs. EMA guideline. Better or worse?. Journal of Pharmaceutical and Biomedical Analysis. 2019 02;165:381-385. https://doi. org/10.1016/j.jpba.2018.12.030

3. Rudzki PJ, Milanowski B, Tajber L, Garbacz G, Jakubowska E, Rychter M, Kutner A, Lulek J. Otwarcie międzynarodowego i międzysektorowego projektu ORBIS (Horyzont 2020). Polskie Towarzystwo Farmaceutyczne. 2018 Jul;74(7):413-6.

4. Rudzki PJ, Biecek P, Kaza M. Incurred Sample Reanalysis: Time to Change the Sample Size Calculation?. The AAPS Journal. 201902 11;21(2). https:// doi.org/10.1208/s12248-019-0293-2

5. Grynkiewicz G, Maruszak W. Open Space Knowledge and Data and Their Influence on Natural Products Based Self-Medication Trends. Cancer Studies and Therapeutics. 2019 Aug;4(3):1-3.

6. Hincker A, Frey K, Rao L, Wagner-Johnston N, Ben Abdallah A, Tan B, Amin M, Wildes T, Shah R, Karlsson P, Bakos K, Kosicka K, Kagan L, Haroutounian S. Somatosensory predictors of response to pregabalin in painful chemotherapy-induced peripheral neuropathy. PAIN. 2019 08;160(8):1835-1846. https://doi. org/10.1097/j.pain.0000000000001577

7. ORBIS project website. https://orbisproject.eu. Accessed 2020 March 17 